\author{
教 育 丵 演 \\ 内科診療の進歩 抗生物質の使い方 ${ }^{*}$ \\ 東京厚生年金病院 \\ 真下 啓明
}

\title{
EDUCATIONAL LECTURE OF USAGE OF ANTIBIOTICS
}

Keimei M Ashimo, MD

Tokyo Kosei Nenkin Hospital, Tokyo

\section{I. はじめに}

抗生物質の歴史が1928年Fleming等のPenicillin G (PCG) の発見に始まることはよく知られてい るが，以来今日まで多数の抗生物質が発見され， さらにその誘導体の数 す多い，1956年Waksman は抗生物質を再定義し, 微生物起源の物質で, 微 量で他の微生物の増殖を阻止あるいは殺隇するむ のとしている.すなわら，抗生物質の主作用は感 染の原因である病原体に直接作用するのである が，感染の場は宿主生体であり，生体は投与され た抗生物質の作用に無縁ではありえず，いわゆる host-parasite-drug relationshipが問題になる。敵を 知り己を知えば百戦危らからずという言葉がある が,この場合敵は病原体であり，己れは抗生物質 であるが，さらに戦場の条件，すなわち宿主生体 の条件を考虑することる重要である。

\section{II. 抗生物質選択の基本}

抗生物質は原因菌に対し，直接作用するもので あるから目標菌に抗菌力のすぐれたるのを選択す るのは当然である. そのため目標となる菌の分

* 本講演は1980年4月5日，東京都港区芝公園 33-1, 東京プリンスホテル原㴧の間にて行なわ れた。
離, 同定, さらに薬物感受性試験結果が重要であ る. 従つて原因菌の分離には最大の努力を厸うへ きで，これに成功すれば抗生物質療法に成功する 可能性は極めて大となる. 原因菌分離に不成功, あるいは原因菌不明な場合は抗生物質療法が不成 功に終る危険は大となることは当然である.

単一の原因菌が証明された場合はそれに最も抗 菌力の優れた抗生物質を選択するが，複数菌が分 離された場合はそれらにすべて有効な広域スぺク トル抗生物質を選択するか，止むをえない場合は 併用を考えることになる．また原因菌不明で推定 で抗生物質を選択する場合も同様である.

\section{II. 抗菌作用機序の立場から}

抗生物質の発見以来何故抗生物質が抗菌作用を 発揮するのかという素朴な疑問はbacterial metabolsim に関する研究を促し，今日多数の抗生物 質の作用機序の悉くとはいえないが溸次明らかに され, 大要次の如く分類され理解されている.
（1）細菌細胞壁生合成障害
（2） 細菌細胞質膜透過性障害
（3）細菌細胞質内蛋白合成障害
（4）必須代謝物質障害
(1)の作用機序を発揮するすのはB-lactam系, 
すなわち penicillin系 (PCs)， cephalosporin系 (CEPs) で代表される．細菌の増殖期には細胞質 の增殖と平行し，細胞壁も合成されて行くが，こ の最終段階でtranspeptidaseに作用し, peptidglycan のcross linkingを阻害するのが， $\beta$-lactam系抗生 物質の作用である。そ結果は細胞壁の破壊から 溶菌 (plasmolysis) K来し殺菌作用 (bactericidal action）となる.な括近年に至り $6 \sim 8$ 二の存在 が知られているPBP (penicillin binding protein) の研究から前述のsingle target theoryが再検討さ れ， $\beta$-lactam放はさらに複雑な機序により，autolytic enzymeであるmurein hydrolase隹より溶菌

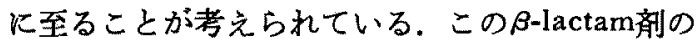
作用が細胞壁合成障害であることは二つの重要な 意義をるつ，一つはその作用の結果が溶菌から殺 菌に至ることであり，他の一つは細菌細胞壁に相 当する部分は哺乳動物の生体細胞には存在せず， 従つて 宿主生体細胞に影響を与えることは理論的にあり えないということである。換言すれば選択毒性 (selective toxicity) といら観点からは極めて優れ た薬物であり，近年の抗生物質開発の方向が専ら B-lactam㓮に集中している大きな根拠となつてい る.

（2）の細胞質膜に作用し，膜透過性に変化を来 するのはColistin (CL), Polymyxin B (PL-B) の如きpolypeptide系, amphotericin B (AMPH), nystatin (NYS) の如きpolyene系抗生物質であり， この作用の結果は殺菌作用となる。しかし，宿主 生体細胞の一部には化学構造上類似した部分むあ り，同一機序により障害を与兄溶血，尿細管障害 等の副作用の危険がある.

（3）の細胞質内蛋白合成障害作用を発揮する ものは tetracycline系 (TCs), chloramphenicol (CP), macrolide系 (MLs), aminoglycoside系 (AGs) 等種類も多く，蛋白合成の種々の段階で これを阻害する。しかし，抗生物質濃度の低下に つれ，細菌は再び蛋白合成が可能となり再増殖 (regrowth) が可能である.すなわら，この作用 は静菌作用（bacteriostatic action）である。蛋白 合成の基本的パターンは宿主生体細胞比いてて 同様であり，従つて大量長期投与では抗菌作用と 同一機序により生体細胞に障害を与えることは避 けえられない，両細胞に対する親和珄の差から薬 物として存立していると考えられる。またGsの 作用梳多面的であり，m-RNAの隌号解䛃のmisreadingのみではないと考えられる。

（4）の必須代謝物障害作用をるつものはSulfa 剂，INH等が代表であり，この場合も静菌作用に 止まる。

以上の抗菌作用機序の立場から考えると殺菌作 用であり，選択毒性のすぐれた $\beta$-lactam系抗生物 質の評価が高いことは当然である。またこの作用 機序が殺菌性か静菌性かといらことは，次の投与 理論にむ根拠を与える。

\section{IV. 抗生物質の投与法一量，間隔，期間}

$\mathrm{TCs}, \mathrm{CP}$ の如き 静菌作用 の抗生物質は当然一 定期間必要有効濃度を炎症部位，すなわち，病原 体所在部位で維持することが必要である。このた めにはT1/2ごとに一定量の投与を繰返せばよいこ とになる.投与回数をへらすためには 1 回投与量 を増加すればよいことになるが，Cmaxが高くな り，静菌性抗生物質では宿主細胞に影響が出やす くなる，一方殺菌性抗生物質ではたと党ば 1 回の 充分量の投与で生体内の感性菌はすぺて殺隇され るはずであるから，1回投与でよいのではないか といら疑問を生ずる。この問題については古く Eagleの理論がある.グラム陽性球菌についての 実験であるが，殺菌性抗生物質との接触により試 験管内に打いて生菌数は1/100K減少するが，1 $\%$ \%生残菌は抗生物質がなくなれば 3 時間後に再 増殖がみられる。充たPCと接触させた菌を動物 大腿筋に接種した実験では，6時間後に再増殖が 始まる. Eagleはこのin vitroとのずれは，生体の 白血球その他の感染防衛力によるとしている．何 故 $1 \%$ の菌が生さ残るかについては，resting state にある菌で代謝を営まず抗生物質をとり込まない ためと説明している，すなわち，殺菌性抗生物質 
であつても一定間隔での絽返し投与が必要であ り，必要有効濃度を下迴る時間を 6 時間以内にす ることが原則とされている。

さて実際に殺菌性抗生物質の投与法の原則が有 意であることを証明しらる症例はすくないが，こ れは抗生物質の投与が撖密である必要がない証拠 ではなく，宿主感染防衛力が感染治瘾の主役であ ることを物語るすのであるう. 投与法が臨床効果 を左右した症例を呈示する。

\section{V. 病態における諸問題一薬動力学の立場から}

(1) 资症果濃度について

炎症の急性渗出期には毛細血管の破綻からplasmaustritt の状態にあり，抗生物質の炎症巣への 移行も良好で，血中濃度の下降時には逆に血中濃 度を上迴る濃度の保たれることもある。これに反 し被包化の強い慢性炎症では病原体所在部位であ る炎症巣への抗生物質の移行は困難なことも多 く，このため比較的用量を多く必要とし，投与期 間も長期に亘り，逆に急性炎症では効果の発現が 早く，投与期間は短くなる.

\section{(2) 肝との関連}

肝との関連において配慮すべき問題の一つは抗 生物質の肝より胆汁への移行である。 $\mathrm{KM}, \mathrm{CP}$, ABPCに対しほ注同程度のMIC值を示すE. coli (NIH-J株) Kよるイヌ実験的胆㐮炎のこれら 3 薬による治療実験では䏣汁移行性のよいABPCの 効果がすぐれ；移行性のわるいKMの効果が劣つ た。すなわち, 胆道采感染症には胆汁移行性の優 れた抗生物質が有利である。

次に抗生物質のなかには肝に打いて代謝され， 不活化あるいは抗菌活性の低い代謝型に転換され るるのがある， $\mathrm{CCl}_{4}$ 肝障害動物における cephalothin (CET), rifampicin (RFP) の胆汁内移行を みる正常時に比して活性型が多く，代謝された desacetyl体がすくない，すなわち，肝障害時の胆 汁の方が抗菌活性は強いことになる。な扣，この CET，RFPを水解する酵素の肝細胞中での所在は aspirin-esteraseの所在部位とは異なる. 例外的に 代謝物の方が菌種によつては抗菌活性が強いこと
もある，例亲ば薬物代謝醉素を活性化する phenobarbital投与動物飞clindamycinを投与し血中濃度 を測定すると対照に比して高い血中濃度がえられ る.これはclindamycinの代謝されたdes-N-methyl 体が多く生産され，生物学的濃度測定に用いられ たSarcina luteaに対する抗菌力がclindamycin自体 より強いことによる。このような代謝による抗菌 活性の変動が臨床効果に如何に影響するかは充分 に明らかではないが配慮すべき問題であろう。

\section{（3）腎との関連}

抗生物質に限らず薬動力学の立場からは，腎機 能の良否は薬物の体内動態に大きな役割を演じ, 効果，副作用の両面㳘響する，抗生物質におい ても腎を主排泄路とするAGs，TCs等においては副 作用と関連し，とくに重要である。AGsでは重䉆 な耳毒性，腎毒性があり，これを防ぐためcritical blood levelを越えないようにbed sideで血中濃度 をmonitorすることが一部ですでに行われている.

腎機能低下時の安全な投与法を求めるには, Wellingの示すごとく抗生物質の排泄速度がCcrと 直線的に相関する場合，正常時と同一投与量で投 与間隔を延長するか，投与間隔は同じとし投与量 を減少するかなどの方法がある。な和AGsの半減 期の算出についてもCcrを用いての簡易計算法る 提陧されている。またその他の抗生物質をふくめ てCcr值との相関において，投与間隔の目標とし て種々の表が発表されている.

腎機能の問題と関連し，今日高令化社会への変 貌に伴い老年者に対する薬物療法は小児薬物療法 の特殊性同様改めて検討する必要に迫られてい る. 抗生物質療法に招いて子老年者に存在する潜 在的腎機能低下が薬物動態に大きく影響し，臨床 効果, 副作用両面に関係しうる. 血中半減期の短

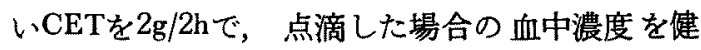
康成人とBUN，s-Crほぼ正常の老年者とで比較す ると老年者では，血中濃度は 2 倍に達する．この よらな老年者もCcrを測定するとその低下が明ら かであり，血中濃度の上昇，血中半減期の延長は 主として腎機能不全に起因すると考えられる。 
たこれら老年者群の体重がすくなかつたことも影 響していると思われる．同じくCEPsでる半減期 の異なるcefamandol (CMD)，6059-Sについて同 様の検討を行ならと半減期の長い汪ど両群の差は すくない。

同様の老年者群に対してAGsの tobramycin (TOB) あるいはaminodeoxy kanamycin (bekanamycin, AKM) $1 \mathrm{mg} / \mathrm{kg}$ 筋注時の 血中濃度をみ ると血中半減期は共に老年者群 で延長するが最 高濃度は対照成人群よりむしろ低い。この傾向は TOB $1 \mathrm{mg} / \mathrm{kg} / \mathrm{h}$ 点滴静注時でも同様である. two compartment model $ら$ pharmakokinetic parameterを求めてみるとこの差はVd(distribution volum) が老年者で大きいことに帰せられるがな険討を 要する.従来AGsの静注は危険視されていたが,た とえばTOBでは $1 \mathrm{mg} / \mathrm{kg}$ の筋注時と 1 時間点滴静注 時とでは最高血中濃度, AUC (area under curve) は汪涪同程度であつた。

\section{VI. 副作用の立場から}

抗生物質療法に伴ら副作用は，本来の抗菌作用 に由来する副作用と抗菌作用とは無縁の副作用と 沈汸られる。

前者は耐性誘導, 耐性選択, さらに菌交代現象 の発生であり，抗菌作用が発揮された結果生ずる わのであるから，いわば不可避的，宿命的なるの である.これに対しては AGsで成功している如く，耐性機序の解明から耐 性菌にも有効な薬物を開発することが極めて重要 である.また消極的にはmisuse，abuseを慎み，不必 要に長期間投与することを擗けるべきであるう.

毒性と考えられる副作用については，当然薬物 側から毒性の除去の努力が払われるべきである が，たとえば，すぐれた抗生物質であるAGsでは 抗菌作用と毒性との解離に未だ成功していない。 各抗生物質によりそれぞれ暴なる毒性がありらる が，臨床上これらを知悉し用いることが大切であ る.

フレルギー性副作用は $\beta$-lactam系抗生物質が主 流になるにつれ，この系統に頻度の高いことから
依然重要な問題である.とくにアナフィラキシー 様ショックの問題は確実な予知法がなく，ABPC 内服によるショック例も報告されており厄介な問 題となつている。現時点では既往歴の確実な聴 取, ショック発生時の早急な対応処置を常に心が けることが重要である。

\section{VI. 併用療法について}

抗生物質が臨床応用せられて以来，抗生物質の 併用㑑魅力ある考方方として繰返し論議されて来 た．各抗生物質の作用機序が漸次明らかれされ， 抗菌力も強くなり，また抗菌スペクトルも拡大さ れるにつれ，今日併用療法の考え方変つて来て いる，しかし，原因菌が単一で明らかな場合，最 るすぐれた1薬による治療が原則であることは変 りがなく，併用が許される場合は以下の限られた 埸合であるう。

(1) 抗菌スペクトルの拡大

原因菌が複数である混合感染に対し，1薬で対 応しえない場合，あるいは原因菌が不明である場 合である：将来抗菌スペクトルがより拡大されれ ばこの立場からの併用は当然すくなくなると考文 られる。感染予防の立場は原因菌不明時と同様で ある。

（2）協力〜相乗效果の期待

最む魅力ある考方方であるが同時に最も実証の むつかしい問題である。それは各薬物ごとに体内 動態が異なり，in vitroで証明された至適比を生 体内で維持しうる保証はきわめて困難であるから である、作用機序の異なる 2 薬の併用の場合む in vitroに括ける条件がin vivo生体内で成立しう るか否かは，慎重に考えねばならない，逆にin vitroでみられる拮抗現象が生体内で成立しらるか 否かも同様であり，いずれも臨床的に効果の証明 せられた場合にのみ併用は許されるべきであろ 5.

また近年 $\beta$-lactamase inhibitor との併用も試及 られつつある。併用による抗菌力の増強にして わ， $\beta$-lactamase inhibitor併用による酎性菌対策 にしてそれぞれより抗菌力の強い，あるいはlact- 
amaseに安定な新物質の出現があればその使命は なくなると考壳られる。

（3）耐性防止

結核症において $2 \sim 3$ 薬の併用により耐性菌出 現率の低下したことはよく知られている，一般感 染症においては投与期間の短いこともあり，この 論拠からの併用療法は認められていない。

（4）副作用防止

かつてSulfa薬に扣いて各薬の溶解度がそれぞ れ独立であることからsulfacombinationとして併 用が行なわれたが，溶解度のすぐれたSulfa薬の出 現に及びこの用法は消隇した。

\section{VII.おわりに}

以上抗生物質の使い方について配虑すべき諸問 題について概括的に述べたのであるが，近年の抗 生物質開発の動向をみると選択毒性においてすぐ れている $\beta$-lactam系抗生物質が中心である。そし てその性格は抗菌力に批いてより強く，抗菌スべ クトルにおいてより広くという方向が求められて いる. 抗菌力がより強くということには異論はな いが，抗菌スペクトルがより広くということは問 題がないわけではない，あらゆる細菌にすべて強 力な抗菌力を持つるのが出現したと仮定すると薬 物選択の重要性はなくなり，また細菌感染症と決 定すればその抗菌薬を投与すればよく，原因菌の 分離，同定，感受性試験等む重要性を失らことに
なるら。しかしあらゆる微生物に有効でない限 りたとえばすべての細菌類を制圧しえたとして も真菌その他は残存することになり，真菌による 菌交代現象が大きな問題となるであろう。

薬物は本来目的とする作用のみを持てばよく， その他の作用は副作用である. 抗生物質において むこの意味からは感染症原因菌にのみ作用する narrow spectrumの性格が望ましく, 宿主生体の生 存がいわゆる常在菌叢とのhomeostasis維持を前提 とするのであれば広域スペクトル抗生物質による その擋乱は生体にとつて必ずしも望ましいことと は言えないであろう.

また逆に将来原因菌にのみ選択的に有効なnarrow spectrumの抗生物質が開発され，細菌と抗生 物質とが1：1K近い対応が成立するようになつ た場合，臨床上その使用に当つての险路は原因菌 の速やかなをた確実な 決定が 可能か否かである う.この意味では臨床細菌学の飛躍的発展が前提 である.

確かに20世紀の遣産と称せられる抗生物質が感 染症治療に果たした役割は大きい。しかし抗生物 質療法が完成されたるのと評価されるためにはな 打解决されるべきいくつかの問題が残されてお り、これらを熟知して臨床に用いることが重要で あると考える。 